\title{
Correction to: Association of ionophores, yeast, and bacterial probiotics alters the abundance of ruminal microbial species of pasture intensively finished beef cattle
}

\author{
Mircéia Angele Mombach ${ }^{1}$ (D - Luciano da Silva Cabral ${ }^{1}$ - Leni Rodrigues Lima ${ }^{1}$. Daniela Cristina Ferreira ${ }^{2}$. \\ Bruno Carneiro e Pedreira ${ }^{3}$. Dalton Henrique Pereira ${ }^{4}$
}

Published online: 13 July 2021

(c) Springer Nature B.V. 2021

Correction to: Tropical Animal Health and Production (2021) 53: 172

https://doi.org/10.1007/s11250-021-02617-2

In the originally published article, the name of the $5^{\text {th }}$ author was incorrectly captured as Bruno Carneirlo e Pedreira. The correct name is Bruno Carneiro e Pedreira as presented in the above authorgroup.

The original article has been corrected.

Publisher's note Springer Nature remains neutral with regard to jurisdictional claims in published maps and institutional affiliations.

The original article can be found online at https://doi.org/10.1007/ s11250-021-02617-2.

Mircéia Angele Mombach

mirceia@zootecnista.com.br

1 Faculty of Agronomy and Animal Science, Universidade

Federal de Mato Grosso, Cuiabá, Mato Grosso, Brazil

2 Department of Biology and Zoology, Universidade Federal de Mato Grosso, Cuiabá, Mato Grosso, Brazil

3 Embrapa Agrossilvipastoril, Box 343, Sinop, Mato Grosso, PO, Brazil

4 Institute of Agrarian and Environmental Sciences, Universidade Federal de Mato Grosso, Sinop, Mato Grosso, Brazil 